\title{
Pengembangan Training Kits Pengukuran Listrik Sebagai Media Pembelajaran pada Mata Pelajaran Memahami Pengukuran Komponen Elektronika di SMK Muhammadiyah 1 Padang
}

\author{
Darwin Rahman Alfasimi ${ }^{1 *}$, Krismadinata ${ }^{2}$, Sukardi $^{3}$, Syukhri $^{4}$ \\ 1,2,3 Jurusan Teknik Elektro, Fakultas Teknik, Universitas Negeri Padang \\ ${ }^{4}$ Jurusan Teknik Elektronika, Fakultas Teknik, Universitas Negeri Padang \\ *Corresponding author, e-mail: darwin_all@yahoo.com
}

\begin{abstract}
Abstrak - Penelitian ini bertujuan untuk mengembangkan training kits pengukuran listrik yang valid, praktis, dan efektif pada mata pelajaran MPKE kelas X TITL di SMK Muhammadiyah 1 Padang. Metode penelitian yang digunakan adalah penelitian dan pengembangan (Research \& Development). Subjek penelitian ini media pembelajaran Training Kits pengukuran listrik dan responden adalah siswa kelas X TITL 1 serta guru mata pelajaran MPKE SMK Muhammadiyah 1 Padang. Berdasarkan hasil penelitian diperoleh validitas dari tim validator bahwa hasil validasi dengan kategori valid. Uji keefektivitasan didapatkan dari hasil ketuntasan klasikal dilihat dari hasil belajar siswa. Hasil posttest siswa yang lulus diatas KKM 21 orang siswa dari 28 orang siswa, nilai siswa yang dibawah KKM 7 orang siswa, maka hasil dari 28 orang siswa yang mengikuti posttest 21 orang siswa dinyatakan lulus, berada pada kategori efektif Berdasarkan penelitian ini dapat disimpulkan bahwa Training Kits ini valid, praktis, dan efektif digunakan untuk mengajar pada mata pelajaran MPKE dan dapat meningkatkan minat belajar siswa sehingga bisa membawa dampak meningkatnya hasil belajar siswa.
\end{abstract}

Kata kunci : Training kits pengukuran listrik, valid, praktis, efektif, Research \& Development

Abstract - This study aims to develop training kits Measurement of electricity is valid, practical, and effective On the subject MPKE Class X TITL at SMK Muhammadiyah 1 padang The method used is research and development. The subject of this study is learning media Training Kits measurement of electricity and respondents are students of class X TITL 1 SMK Muhammadiyah 1 Padang and subject teachers MPKE SMK Muhammadiyah 1 Padang. Based on the research results obtained the validity from validator team that validation result with validator valid category. Test effective obtained from the results of classical completeness Seen from student learning outcomes. Posttest result of students who passed above KKM 21 students from 28 students Student scores below KKM 7 students, then the result of the 28 students who follow posttes 21 students graduated 21 students who graduated, Being in the effective category. Based on this research can be concluded that Training Kits is valid practical, and effective use to teach on subjects MPKE and can increase students' interest in learning so that it can bring the impact of increasing student learning outcomes.

Keywords : Training kits electrical measurements, valid, practical, effective, Research \& Development

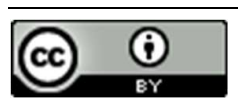
distribution, and reproduction in any medium, provided the original work is properly cited. $\mathbb{C} 2018$ by Author and Universitas Negeri Padang

\section{Pendahuluan}

Pendidikan adalah suatu hal yang sangat penting dalam suatu negara, kemajuan suatu negara akan tercermin salah satunya dari kualitas pendidikan yang ada pada suatu negara tersebut. Berkualitas atau tidaknya pendidikan itu tergantung pada sistem pendidikan yang diterapkan. Apabila sistem pendidikan yang diterapkan sudah baik maka pendidikan yang dihasilkanpun juga akan semakin berkualitas, namun jika sebaliknya sistem pendidikan yang diterapkan belum baik dan tidak dirumuskan secara 
matang maka kualitas pendidikan juga akan menurun.

SMK Muhammadiyah 1 Padang merupakan salah satu jalur pendidikan formal pendidikan menegah kejuruan yang memiliki tujuan yang sama dengan tujuan sekolah menengah kejuruan pada umumnya yakni menghasilkan lulusan yang berkualitas memiliki keahlian khusus sesuai dengan bidang keahliannya, serta siap kerja. Dalam mencapai tujuan yang telah dirumuskan dan direncanakan oleh sekolah tersebut, tentuada beberapa unsur yang harus dipertimbangkan dan dilakukan. Salah satu dari beberapa unsur tersebut adalah guru, hal ini dikarenakan guru memegang peranan penting dalam proses pembelajaran dan hasil belajar siswa di kelas. Guru merupakan faktor utama dalam usaha meningkatkan mutu pendidikan sekolah yang pada gilirannya akan sangat mempengaruhi kemajuan masyarakat yang menjadikan masyarakat semakin rasional dan teknologis, serta membutuhkan jasa sekolah dan atau guru yang bermutu [9].

Profesionalitas seorang guru dalam melaksanakan proses pembelajaran di kelas akan mempengaruhi dan menentukan hasil belajar peserta didikselama belajar di sekolah yang pada akhirnyatentu juga akan mempengaruhi tercapai atau tidaknya tujuan sekolah. Profesionalitas seorang guru dalam melaksanakan proses pembelajaran di kelas, dapat dilihat dari persiapan awal mengajar, metode mengajar yang diterapkan, serta media pembelajaran yang digunakan pada saat proses pembelajaran berlangsung. Media pembelajaran yang dimaksud adalah media yang dapat menunjang motivasi belajar siswa dan menghilangkan rasa bosan siswa pada saat mengikuti proses pembelajaran di kelas.

Berdasarkan hasil observasi yang dilakukan terhadap proses pembelajaran di SMK Muhammadiyah 1 Padang, khususnya pada Mata Pelajaran Memahami Pengukuran Komponen Elektronika,Guru cenderung menggunakan papan tulis sebagai media dalam proses pembelajaran di kelas dan masih menggunakan media pembelajaran seadanya, dengan alasan mudah dalam penyajian dan persiapannya.

Pelaksanaan pembelajaran pada mata pelajaran Memahami Pengukuran Komponen Elektronika kelas X di SMK Muhammadiyah 1 Padang. Ketika proses pembelajaran dimulai, seorang guru terfokus mencatat materi yang akan dibahas di papan tulis, kemudian guru akan menjelaskannya, siswa mencatat dan mendengarkan materi yang telah ditulis dan dijelaskan oleh guru tersebut. Pada saat proses pembelajaran guru cenderung hanya memilih media papan tulis dan penggunaan media yang belum optimal dalam penyampaian materi sehingga pemahaman siswa terhadap pelajaran berkurang dan hasil belajar siswa rendah. Berikut tabel rekapitulasi nilai murni hasil belajar siswa pada semester satu kelas X TITLdi SMK Muhammadiyah 1 Padang tahun ajar 2016-2017 berdasarkan KKM. Tabel 1. Ketuntasan Belajar Siswa pada Mata Pelajaran MPKE Semester Satu Kelas X TITL SMK Muhammadiyah 1 Padang Tahun Ajar 2016-2017.

Tabel 1: Ketuntasan hasil belajar

\begin{tabular}{|c|c|c|c|c|c|c|}
\hline \multirow{2}{*}{ Kelas } & \multirow{2}{*}{$\begin{array}{c}\text { Jumlah } \\
\text { Siswa }\end{array}$} & K & \multicolumn{2}{|c|}{$\begin{array}{c}\text { Siswa } \\
\text { Tuntas }\end{array}$} & \multicolumn{2}{|c|}{$\begin{array}{c}\text { Siswa } \\
\text { Tidak } \\
\text { Tuntas }\end{array}$} \\
\cline { 4 - 7 } & & M & Jumlah & $\%$ & Jumlah & $\%$ \\
\hline X L1 & 31 & 80 & 14 & 45.1 & 16 & 51.6 \\
\hline X L2 & 28 & 80 & 13 & 46.4 & 15 & 53.5 \\
\hline \multicolumn{3}{|c|}{ Rata-Rata } & \multicolumn{3}{|c|}{$\mathbf{4 5 . 7 \%}$} & \multicolumn{2}{|c|}{$\mathbf{5 2 . 5 \%}$} \\
\hline
\end{tabular}

Sumber : Guru Mata Pelajaran MPKE

Solusi dari pihak guru untuk menyikapi hal tersebut adalah memberikan program remedial. Program remedial merupakan pembelajaran yang diberikan kepada siswa yang belum mencapai KKM dengan menggunakan metode tertentu yang diakhiri dengan penilaian kembali. Namun, pelaksanaan program remedial dirasa tidak efektif karena membutuhkan waktu yang lama dan hasil dari ujian ulang tidak boleh melebihi KKM yang ditentukan. Oleh karena itu diperlukan inovasi guru terbaru yang mampu membantu mengurangi hambatan yang dihadapi siswa dalam pembelajaran MPKE dengan membuat media pembelajaran yang baik untuk melaksanakan pembelajaran dengan melatih dan mengembangkan kemampuan siswa untuk menyelesaikan masalah dan merangsang keinginan untuk berpikir dalam proses pembelajaran. Media pembelajaran yang digunakan adalah media Training Kits Pengukuran Listrik, yaitu media pembelajaran yang dilengkapi dengan komponen elektronika, alat ukur.

\section{STUdi PUSTAKa}

Media berasal dari bahasa latin dan merupakan bentuk jamak dari kata medium yang secara harfiah berarti perantara atau pengantar. Media adalah perantara atau pengantar pesan dari pengirim ke penerima pesan [15]. Media pembelajaran adalah segala sesuatu yang dapat menyampaikan atau menyalurkan pesan dari suatu sumber secara terencana, sehingga terjadi lingkungan belajar yang kondusif dimana 
penerimanya dapat melakukan proses belajar secara efesien dan efektif [4]. Berdasarkan definisi pendapat para ahli diatas dapat disimpulkan bahwa media adalah segala sesuatu yang dapat digunakan untuk menyalurkan dari sumber dengan terencana sehingga tercipta lingkungan belajar yang kondusif, efektif, dan efesien. Berdasarkan definisi pendapat para ahli diatas dapat disimpulkan bahwa media adalah segala sesuatu yang dapat digunakan untuk menyalurkan dari sumber dengan terencana sehingga tercipta lingkungan belajar yang kondusif, efektif, dan efesien.

Penggunaan media dalam pelaksanaan proses pembelajaran dapat membantu mempermudah tercapainya tujuan pembelajaran yang diinginkan dan dapat mempertinggi tingkat keberhasilan dalam proses pembelajaran [14]. Pemilihan media dalam belajar perlu mempertimbangkan beberapa hal sedangkan tidak semua media bisa digunakan dalam beberapa pembelajaran. Ada kalanya media yang digunakan mempersulit pencapaian tujuan belajar.Agar penggunaan media sesuai dengan kebutuhannya, maka perlu diketahui kriteria pemilihan media dalam belajar. Kriteria pemilihan media sebagai berikut [2]:

a. Sesuai dengan tujuan yang ingin dicapai.

b. Tepat untuk mendukung isi pelajaran yang sifatnya fakta, konsep, prinsip atau generalisasi.

c. Praktis, luwes dan bertahap.

d. Pengelompokan sasaran.

e. Mutu teknis.

Berdasarkan beberapa pengertian yang telah dibahas di atas, maka dapat diambil jalan tengah pernyataan bahwa media pembelajaran adalah suatu bentuk sarana yang dapat merangsang pikiran, perasaan, perhatian dan minat siswa sehingga proses belajar yang berkualitas dan mencapai kompetensi yang diharapkan.

\subsection{Pengembangan Media Pembelajaran}

Media dikelompokkan dalam dua jenis, yaitu media jadi karena sudah ada di pasaran luas dalam keadaan siap pakai, dan media rancangan yang dipersiapkan secara khusus untuk maksud atau tujuan pembelajaran tertentu [15].

Secara umum, urutan dalam mengembangkan media sebagai berikut [15]:

a. Menganalisis kebutuhan dan karakteristik siswa.

b. Merumuskan tujuan instruksional dengan operasional dan khas. c. Merumuskan butir-butir materi secara terinci yang mendukung tercapainya tujuan.

d. Mengembangkan alat pengukur keberhasilan.

e. Menulis naskah media.

f. Mengadakan tes dan revisi.

Dari pendapat beberapa ahli di atas dapat disimpulkan bahwa pada suatu kondisi perlu dilakukan pengembangan media pembelajaran dalam bentuk media rancangan (media by design) yang dipersiapkan sehingga tujuan pembelajaran bisa tercapai dengan baik dengan memperhatikan urutan dan tata cara pengembangan media itu sendiri.

\subsection{Mata Pelajaran MPKE}

Memahami Pengukuran Komponen Elektronika merupakan salah satu mata pelajaran yang mendidik, melatih, dan menyiapkan siswa untuk mampu menguasai dan memahami komposnen pasif dan alat ukur untuk pengukuran besar besaran listrik serta mampu menggunakannya. Materi yang terkandung di dalamnya banyak terdapat materi yang bersifat abstrak, seperti bentuk fisik alat ukur, rangkaian penyusun, cara penggunaan, cara membaca hasil pengukurannya, serta prinsip kerja.Materi yang terkandung di dalam Mata Pelajaran Memahami Pengukuran Komponen Elektronika ini akan berkaitan dengan mata pelajaran produktif lainnya.

\subsection{Hasil Belajar}

Hasil belajar adalah tingkat keberhasilan yang dicapai oleh siswa setelah mengikuti suatu kegiatan pembelajaran, keberberhasilan tersebut ditandai dengan skala nilai berupa huruf, kata, dan angka.Sedangkan penilaian hasil belajar adalah pemberian nilai terhadap hasil-hasil belajar yang dicapai siswa dengan kriteria tertentu.hasil belajar adalah proses pencapaian siswa dari proses belajar yang dilaluinya baik berupa pengetahuan, keterampilan maupun sikap [15], [6].

Guru perlu mengadakan penilaian pada pembelajaran karena penilaian merupakan usaha untuk memperoleh informasi tentang perolehan hasil belajar peserta didik secara menyeluruh, baik pengetahuan, konsep, nilai, maupun keterampilan proses. Hal ini dapat digunakan oleh guru sebagai balikkan maupun keputusan yang sangat diperlukan dalam menentukan strategi mengajar 
yang tepat maupun dalam memperbaiki proses pembelajaran.

Berdasarkan pendapat para ahli dapat disimpulkan bahwa hasil belajar adalah sebagai tolak ukur yang digunakan untuk menentukan keberhasilan peserta didik dalam menguasai materi yang diberikan oleh pendidik.

\subsection{Validitas, Kepraktisan, Efektif Media}

Validitas adalah suatu ukuran yang menunjukkan tingkat kevalidan dan kesahihan suatu instrument. Instrument yang valid berarti alat ukur yang digunakan untuk mendapatkan data dan dapat mengukur apa saja yang hendak diukur.Sisi lain dari pengertian validitas adalah aspek kecermatan pengukuran. Suatu alat ukur yang valid tidak hanya mampu mengahsilkan data yang tepat akan tetapi juga harus memberikan gambaran yang cermat mengenai data tersebut. Praktis artinya mudah dan senang dalam pemakaiannya.

Kepraktisan berkaitan dengan keterpakaian media Training Kits yang dikembangkan. Kepraktisan meliputi kemudahan penggunaan, waktu yang diperlukan dalam pelaksanaan, keterampilan serta manfaat. Pertimbangan praktikalitas dapat dilihat dari aspek-aspek berikut [18]:

a. Kemudahan penggunaan, meliputi: mudah diatur, disimpan, dan dapat digunakan sewaktu-waktu

b. Waktu yang diperlukan dalam pelaksanaan sabaiknya singkat, cepat dan tepat.

c. Mudah di interpretasikan oleh guru maupun oleh guru lain.

d. Bisa digunakan sebagai pengganti dan untuk variasi.

Sebaiknya memiliki karakteristik biaya murah dan dapat dijangkau oleh guru atau sekolah yang hendak menggunakannya.

Keefektifan media pembelajaran dapat diartikan dengan keberhasilan yang dicapai setelah media tersebut digunakan. Keberhasilan pembelajaran dalam kelas dapat diukur dengan persentase jumlah peserta didik yang mampu memahami dan dinyatakan lulus dari materi yang diajarkan

\section{Metode}

Jenis penelitian ini merupakan penelitian pengembangan (Research and Development) yang biasa dikenal dengan istilah R\&D. Pendekatan R \&
D merupakan suatu proses yang digunakan untuk mengembangkan dan memvalidasi produk-produk pendidikan, seperti modul dan media pembelajaran. Research and Development adalah metode penelitian yang digunakan untuk menghasilkan produk tertentu, dan menguji keefektifan produk.[12]

Subjek penelitian adalah media Training kits Pengukuran listrik pada mata pelajaran MPKE. Responden penelitian adalah kelas X TITL dan Guru mata pelajaran MPKE di SMK Muhammadiyah 1 Padang. Karena kelas TITL terdiri dari dua kelas maka dipilih salah satu kelas yang akan dijadikan responden, teknik pengambilan sample dilakukan secara acak (Random Sampling) dengan cara melakukan undian. Dalam undian ini terpilih kelas X TITL 1, maka kelas inilah yang dijadikan kelas ekperimen. Jadi, kelas X TITL 1 merupakan kelas eksperimen yang berjumlah 28 orang siswa.berikut merupakan langkah-langkah penelitian seperti yang terlihat pada gambar 1 .

\section{a. Potensi Masalah}

Tujuan dari tahapan ini adalah untuk menetapkan potensi dan masalah yang akan diangkat pada penelitian ini untuk dipecahkan solusi dari potensi dan masalah tersebut.

\section{b. Pengumpulan Informasi}

Pengumpulan informasi bertujuan untuk mengetahui kebutuhan media ditinjau dari segi karakteristik mata pelajaran, siswa, dan hasil diskusi dengan guru mata pelajaran.

\section{c. Desain Produk}

Desain traiing kits dibuat mengacu pada prinsipprinsip media pembelajaran yang baik. Kegiatan pada tahap ini meliputi: melakukan perencanaan awal, membuat desain tertulis, mempersiapkan peralatan dan bahan, dan melakukan pembuatan training kits. Adapun desain traiing kits pengukuran listrik yang akan dikembangkan dapat dilihat pada gambar 2 .

\section{d. Validasi Desain}

Proses validasi desain dilakukan oleh beberapa orang para ahli/pakar yang berpengalaman dalam menilai desain media pembelajaran. rancangan desain training kits yang akan divalidasi disiapkan dalam bentuk lembaran validasi. Validator terdiri dari dosen pengukuran listrik dan dosen media pembelajaran Jurusan Teknik Elektro selain itu guru mata pelajaran di SMK Muhammadiyah 1 
Padang dan setiap validator diminta untuk menilai rancangan desain training kits tersebut.

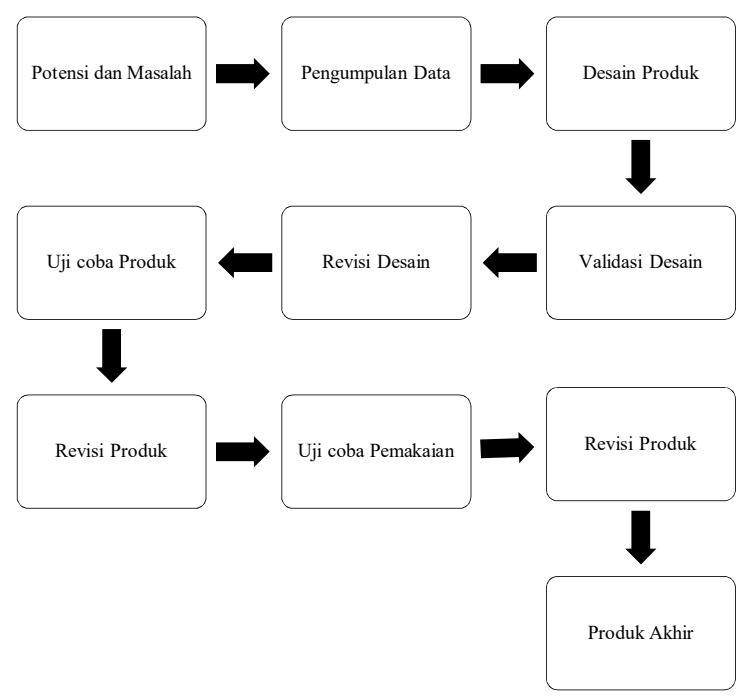

Gambar 1. Bagan Langkah Penelitian

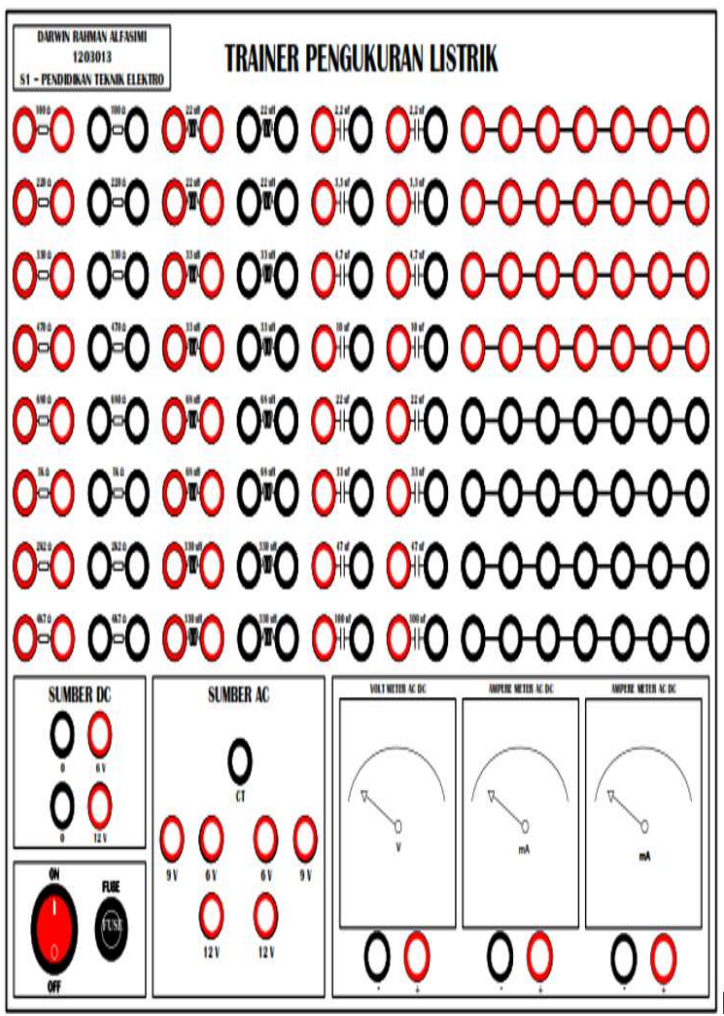

Gambar 2. Training Kits Pengukuran Listrik

\section{e. Revisi Desain}

Revisi desain dilakukan berdasarkan hasil validasi media oleh validator. Perbaikan juga mempertimbangkan saran yang diberikan oleh validator.

\section{f. Pembuatan Training Kits}

Proses pembuatan Training Kits dapat dilaksanakan setelah rancangan desain Training Kits sudah divalidasi dan disahkan oleh validator. Training Kits yang dihasilkan harus sesuai dengan rancangan desain yang telah divalidasi. Selanjutnya disiapkan lembaran validasi untuk menguji kualitas dari Training Kits yang dikembangkan ini

\section{g. Validasi Media Training Kits}

Setelah proses pembuatan alat selesai, dilanjutkan dengan proses validasi uji coba pemakaian oleh validator. Alat Training Kits ini diuji coba pemakaiannya dihadapan validator, kemudian validator menilai dan memberikan dan memberikan rekomendasi Training Kits sudah valid atau tidaknya.Jika Training Kits ini dinyatakan sudah valid maka dilanjutkan ke proses berikutnya. Namun jika belum valid maka perlu dilakukan revisi kembali sampai dinyatakan valid oleh validator.

\section{h. Revisi I}

Revisi I dilakukan untuk menyempurnakan Training Kits sesuai hasil validasi dan saran-saran yang diberikan oleh validator. Setelah dilakukan proses revisi, hasilnya kembali akan dikomfirmasi kepada validator untuk mendapatkan persetujuan.

\section{i. Uji Coba Pemakaian}

Uji coba produk dilakukan setelah dilakukannya perbaikan produk dan perangkat pembelajaran telah valid. Perangkat tersebut diuji coba di kelas X TITL yang berjumlah 20 orang siswa dan guru mata pelajaran MPKE hal ini dilakukan untuk melihat kepraktisan media Training Kits Pengukuran listrik. Sumber data kepraktisan adalah siswa dan guru mata pelajaran sebagai pengguna media yang dikembangkan.

\section{j. Produk Akhir}

Produk AkhirTraining Kitsdiperoleh setelah Training Kitsyang dikembangkan berada pada kategori: (1) Valid oleh validator berdasarkan hasil uji validasi Training Kits, (2) Praktis dan efektif berdasarkan hasil uji coba produk, dan (3) Praktis dan efektif berdasrkan hasil uji coba pemakaian. 


\subsection{Instrumen Penelitian}

Instrument penelitian yang digunakan dalam mengumpulkan data penelitian ini adalah:

\section{a. Angket Validasi Media Training Kits}

Angket validasi adalah suatu ukuran yang menunjukkan tingkat kevalidan atau kesahihan suatu instrument. Jenis validitas yang digunakan adalah uji validitas konstruk yang megacu pendapat para pakar dan ahli (Judgment Expert).Validator media terdiri dari 3 orang ahli dan guru MPKE.

\section{b. Angket Kepraktisan Media Training Kits}

Angket kepraktisan media pembelajaran dimaksud untuk mengetahui tingkat kepraktisan media Training Kits Pengukuran Listrik pada mata pelajaran memahami pengukuran komponen elektronika.Praktis media adalah guru mata pelajaran dan siswa sebagai pengguna.Angket kepraktisan ini mengacu pada respon guru dan siswa.Kisi-kisi angket dapat dilihat pada

\section{c. Tes Objekif}

Tes objektif digunakan untuk mengetahui penguasa materi siswa terhadap materi yang diajarkan. Tes diberikan setelah dilakukan kegiatan belajar mengajar media yang dikembangkan. Setelah diberi tes maka dilakukan penskoran untuk mengetahui siswa yang memiliki nilai $\geq 80$. Hal ini bertujuan untuk mengetahui tingkat keefektifan media dalam mata pelajaran MPKE

\subsection{Teknik Analisa Data}

\section{a. Analisis Validitas Training Kits}

Pemberian nilai validitas dengan cara:

Nilai Validitas $=\frac{\text { skor yang diperoleh }}{\text { skor maksimum }}$

Selanjutnya nilai hasil validasi dikategorikan sesuai dengan Tabel 2:

Tabel 2. Kategori Validasi Produk

\begin{tabular}{|l|l|}
\hline TingkatPencapaian & \multicolumn{1}{|c|}{ Kategori } \\
\hline$>0,6$ & Valid \\
\hline$<0,6$ & Tidak \\
Valid \\
\hline
\end{tabular}

Sumber: [5] b. Analisis Keptaktisan Training Kits

Pemberian nilai kepraktisan dengan cara:

Skor nilai ideal

$=\frac{\text { skor yang diperoleh }}{\text { skor maksimum }} \times 100 \%$

Selanjutnya nilai hasil validasi di kategorikan sesuai dengan Tabel 3:

Tabel 3. Kategori Kepraktisan Produk

\begin{tabular}{|c|c|c|}
\hline No & $\begin{array}{c}\text { Tingkat } \\
\text { Pencapaian (\%) }\end{array}$ & Kategori \\
\hline 1 & $90-100$ & Sangat Praktis \\
\hline 2 & $80-89$ & Praktis \\
\hline 3 & $65-79$ & Cukup Praktis \\
\hline 4 & $55-64$ & Kurang Praktis \\
\hline 5 & $0-54$ & Tidak Praktis \\
\hline
\end{tabular}

Sumber: [11]

\section{c. Analisis Keefektivitas Media}

Efektivitas produk dilihat dari jumlah siswa yang memperoleh nilai diatas KKM.Siswa yang dinyatakan tuntas pada nilai KKM diatas 80 .

Perolehan nilai siswa dihitung menggunakan rumus berikut:

$$
K=\frac{\text { Jumlah Siswa Tuntas }}{\text { Jumlah Seluruh Siswa }} \times 100 \%
$$

Jumlah siswa yang memperoleh nilai diatas 80 dipersentasekan dan dikategorikan sesuai Tabel 4.

Tabel 4. Kategori Efektifitas Produk

\begin{tabular}{|c|c|c|}
\hline No & $\begin{array}{c}\text { Tingkat } \\
\text { Pencapaian (\%) }\end{array}$ & Kategori \\
\hline 1 & $90-100$ & Sangat Efektif \\
\hline 2 & $80-89$ & Efektif \\
\hline 3 & $65-79$ & Cukup Efektif \\
\hline 4 & $55-64$ & Kurang Efektif \\
\hline 5 & $0-54$ & Tidak Efektif \\
\hline
\end{tabular}

Sumber: [11] 


\section{HASIL dAN PEMbahasan}

\section{a. Hasil Validasi}

Setelah media Training Kits pengukuran listrik di validasi oleh validator, selanjutnya dilakukan rekapitulasi data hasil validasi kemudian dilakukan analisis data. Hasil validasi media dapat dilihat pada Tabel 5:

Tabel 5. Hasil Validitas Oleh Validator Media

\begin{tabular}{|c|c|c|c|}
\hline Validator & $\begin{array}{c}\text { Perolehan } \\
\text { Skor }\end{array}$ & $\begin{array}{c}\text { Nilai } \\
\text { kevelidan }\end{array}$ & $\begin{array}{c}\text { Kategor } \\
\mathbf{i}\end{array}$ \\
\hline 1 & 73 & 0,91 & Valid \\
\hline 2 & 73 & 0,91 & Valid \\
\hline 3 & 69 & 0,86 & Valid \\
\hline 4 & 64 & 0,80 & Valid \\
\hline
\end{tabular}

\section{b. Hasil Kepraktisan}

Uji praktikalitas bertujuan untuk melihat kepraktisan media yang dikembangkan pada siswa kelas X SMK Muhammadiyah 1 Padang.Media yang telah dinyatakan valid setelah itu di uji penggunaanya dengan jumlah responden 20 orang siswa dan 1 guru mata pelajaran memahami pengukuran komponen elektronika sebagai pengguna media.maka didapatkan hasil $80 \%$ siswa memberikan nilai Praktis dan 20\% siswa memberikan nilai Sangat Praktis.

Guru sebagai pengguna media Training Kitsnilai kepraktisan media sebesar $80 \%$ dengan kategori Praktis.

\section{c. Hasil Efektifitas}

Uji efektifitas media pembelajaran training kits ini dilakukan dengan cara melihat ketuntasan belajar secara klasikal setelah penggunaan media ini. Ketuntasan klasikal dilihat pada hasil belajar siswa melalui posttest siswa kelas X TITL yang berjumlah 28 orang siswa. Hasil posttest siswa yang lulus diatas KKM 21 orang siswa dari 28 orang siswa, nilai siswa yang dibawah KKM 7 orang siswa, maka hasil dari 28 orang siswa yang mengikuti posttest 21 orang siswa dinyatakan lulus dari 28 orang siswa, 21 orang siswa yang lulus menunjukkan ketuntasan klasikal 75\%.

Berdasarkan penelitian ini dapat disimpulkan bahwa Training Kits ini valid, praktis, dan efektif digunakan untuk mengajar pada mata pelajaran MPKE dan dapat meningkatkan minat belajar siswa sehingga bisa membawa dampak meningkatnya hasil belajar siswa. Penelitian pengembangan Training Kit pengukuran listrik ini memiliki keterbatasan yaitu hanya terbatas pada satu KD dari lima kompetensi dasar yang ada pada pelajaran MPKE dan uji coba pada satu kelas. Dikarenakan keadaan dan waktu yang terbatas maka penelitian dilakukan hanya mengangkat satu KD saja.Training Kit pengukuran listrik dapat digunakan oleh sekolah lain dalam mata pelajaran yang sama maupun mata pelajaran yang berhubungan dengan Pengukuran listrik.

Berdasarkan penelitian ini dapat disimpulkan bahwa Training Kits ini valid, praktis, dan efektif digunakan untuk mengajar pada mata pelajaran MPKE dan dapat meningkatkan minat belajar siswa sehingga bisa membawa dampak meningkatnya hasil belajar siswa di TITL SMK Muhammadiyah 1 Padang.

\section{KESIMPULAN}

Berdasarkan hasil penelitian yang telah dilakukan, maka dapat disimpulkan bahwa penelitian pengembangan trainer pengukuran listrik yang valid, praktis dan efektif pada mata pelajaran Memahami pengukuran komponen elektronika kelas X TITL SMK Muhammadiyah 1 Padang adalah:

1. Berdasarkan hasil validasi oleh 4 validator dengan nilai validasi kategori valid.

2. Berdasarkan hasil rekapitulasi kepraktisan yang diperoleh dengan kategori Praktis. Sedangkan guru sebagai pengguna media Training Kits yang dikembangkan didapatkan nilai kepraktisan media dengan kategori praktis.

3. Efektifitas penggunaan media pembelajaran Training Kits pengukuran listrik diperoleh dari tingkat ketuntasan belajar klasikal sehingga media pembelajaran Training Kits yang dikembangkan sudah efektif untuk digunakan untuk proses pembelajaran.

4. Penelitian ini membuktikan bahwa Training Kits pengukuran listrik yang dikembangkan dapat digunakan untuk pembelajaran Memahami Pengukuran Komponen Elektronika.

\section{DAfTAR PUStaka}

[1] Arikunto, Suharsimi. Dasar-Dasar Evaluasi Pendidikan. Jakarta: PT. Bumi Aksara(2013)

[2] Arsyad, Azhar.Media Pembelajaran. Jakarta: Raja Wali Press.(2010)

[3] . Media Pembelajaran, Jakarta : PT. Raja Grafindo Persada.(2011) 
[4] Asyhar, Rayandra. 2011. Kreatif Mengembangkan Media Pembelajaran. Jakarta: Gaung Persada Press.

[5] Azwar, Saifuddin. Reliabilitas dan Validitas. Yogyakarta: Pustaka Belajar(2015).

[6] Dimyati dan Mudjiono. 2010. Belajar dan Pembelajaran. Jakarta: PT Rineka Cipta.

[7] Emzir. Metodologi Penelitian Pendidikan: Kuantitatif dan Kualitatif. Jakarta: Rajawali Press (2010)

[8] Hamalik, Oemar. Media Pendidikan. Bandung: Citra Aditya Bakti(1994)

[9]_.Perencanaan Pembelajaran Berdasarkan Pendekatan Sistem. Jakarta: Bumi Aksara(2010)

[10] Mukhtar Dan Iskandar. Desain Pembelajaran Berbasis Teknologi Informasi dan Komunikasi. Jakarta: Gaung Persada Press(2010)

[11] Riduwan.. Belajar Mudah Penelitian Untuk Guru, Karyawan dan Peneliti Pemula. Bandung: Alfabeta (2010)

[12] Sugiyono. Metode Penelitian Kuantitatif, Kualitatif Metode Penelitian \& Pengembangan Research and Development. Bandung: Alfabeta (2013)

[13] Metode Penelitian Kuantitatif, Kualitatif dan $R \& D$. Bandung: Alfabeta.(2014)

[14] Rohani, Ahmad. Media Instruksional Edukatif. Jakarta: Rajawali Press (1997)

[15] Sadiman, Arif S. dkk. Media Pendidikan: Pengertian, Pengembangan, dan Pemanfaatannya. Jakarta: PT. Raja Grafindo Persada (2012)

[16] Sudjana, Nana. Penilaian Hasil Proses Belajar Mengajar. Bandung: Remaja Rosdakarya (2009)

[17] Sudjana dan Rivai.Media Pengajaran. Bandung: Sinar Baru Algensindo(2011)

[18] Sukardi. Evaluasi Pendidikan: Prinsip dan Operasionalnya. Jakarta: Bumi Aksara(2012)

[19] Suryani.Komunikasi Terapeutik: teori dan praktik. Jakarta: EGC(2006)

\section{BiodataPenulis}

Darwin Rahman Alfasimi, lahir di Takengon, 21 Februari 1994. Menyelesaikan pendidikan S1 di Jurusan Teknik Elektro Program Studi Pendidikan Teknik Elektro Universitas Negeri Padang tahun 2017.

Krismadinata, lahir di Padang, 11 September 1977. Menyelesaikan studi S1 di Universitas Andalas, S2 di Institut Teknologi Bandung, dan S3 di Universitas Malaya. Dosen di Jurusan Teknik
Elektro Fakultas Teknik Universitas Negeri Padang sejak tahun 2000 sampai sekarang

Sukardi, lahir di Semerap Kerinci, 10 Mei 1961. Menyelesaikan studi S1 di IKIP Padang, S2 di Institut Teknologi Bandung dan S3 di Universitas Negeri Yogyakarta. Dosen di Jurusan Teknik Elektro Fakultas Teknik Universitas Negeri Padang sejak tahun 1986 sampai sekarang

Syukhri, lahir di Padang, 9 Juni 1978. Sarjana Teknik Elektro dari Institut Teknologi Padang, lulus 2006. Tahun 2013 memperoleh gelar Magister Chief Information Officer pada Pascasarjana Fakultas Teknik Universitas Negeri Padang. System Administrator pada Unit Pelaksana Teknis Pengembangan Teknologi Informasi dan Komunikasi (UPT PTIK) Universitas Negeri Padang dari 2006 sampai 2017. Staf pengajar pada Jurusan Teknik Elektronika FT UNP sejak tahun 2017- sekarang. 
